\title{
Predicting visual recovery following optic nerve decompression for chronic optic neuropathy
}

\author{
Neil R. Miller
}

Received: 3 May 2009 / Accepted: 8 May 2009/Published online: 29 May 2009

(C) Springer-Verlag 2009

Sir,

I read with interest the article by Bulters and co-workers in the May 2009 issue of Acta Neurochirurgica, describing the visual results following optic nerve decompression for chronic optic neuropathy [1]. In their article, the authors emphasize that many patients with chronic compressive optic neuropathies experience significant visual improvement after decompression of the optic nerve, regardless of their preoperative visual function or duration of visual symptoms. They also emphasize the difficulty in predicting those patients who have a potential for visual improvement and those who do not. It is becoming increasingly clear that this difficulty may be addressed by using optical coherence tomography (OCT), an imaging study that uses infrared light waves that reflect off the internal microstructure within biological tissues. OCT provides an objective and reproducible assessment of the thickness of the retinal nerve fiber layer (RNFL) of the eyethe layer that contains the axons that comprise the optic nerve. The normal thickness of the RNFL is about $100 \mu \mathrm{m}$ [2], whereas in eyes with chronic complete blindness due to optic nerve disease, the thickness is $40-45 \mu \mathrm{m}$ [3]. The thinner the RNFL in a patient with an intracranial lesion that compresses the optic nerve, the more atrophy has occurred and the less likely it is for visual recovery to occur after optic nerve decompression. The prognostic value of OCT in patients with lesions compressing the optic nerve has been assessed by two different groups, both of which have concluded that this noninvasive imaging technique can be used as a prognostic tool in such patients $[4,5]$. Indeed, the study by Jacob et al. [5] concluded that in patients with

N. R. Miller $(\bowtie)$

John Hopkins Hospital,

Baltimore, MD, USA

e-mail: nrmiller@jhmi.edu pituitary adenomas compressing the anterior visual pathways, the odds of complete recovery after 3 months from the initial visual field defect was multiplied by 1.29 for each increase by $1 \mu \mathrm{m}$ of mean RNFL, independent from age and duration of symptoms. I commend the authors for emphasizing that even patients with chronically poor visual function from compressive optic neuropathy can recover after decompression and suggest that RNFL thickness as measured by OCT is a better prognostic indicator of potential visual recovery in such patients than the time-honored factors of preoperative visual status and duration of visual symptoms.

\section{References}

1. Bulters DO, Shenouda E, Evans BT, Mathad N, Lang DA (2009) Visual recovery following optic nerve decompression for chronic compressive optic neuropathy. Acta Neurochir (Wien) 151:325334. doi:10.1007/s00701-009-0192-x

2. Paunescu LA, Schuman JS, Price LL, Stark PC, Beaton S, Ishikawa H, Wollstein G, Fujimoto JG (2004) Reproducibility of nerve fiber thickness, macular thickness, and optic nerve head measurements using StratusOCT. Invest Ophthalmol Vis Sci 45:1716-1724. doi:10.1167/iovs.03-0514

3. Chan CKM, Miller NR (2007) Peripapillary nerve fiber layer thickness measured by optical coherence tomography in patients with no light perception from long-standing nonglaucomatous optic neuropathies. J Neuroophthalmol 27:176-179. doi:10.1097/ WNO.0b013e31814b1ac4

4. Danesh-Meyer HV, Papchenko T, Savino PJ, Law A, Evans J, Gamble GD (2008) In vivo retinal nerve fiber layer thickness measured by optical coherence tomography predicts visual recovery after surgery for parachiasmal tumors. Invest Ophthalmol Vis Sci 49(5):1879-1885. doi:10.1167/iovs.07-1127

5. Jacob M, Raverot G, Jouanneau E, Borson-Chazot F, Perrin G, Rabilloud M, Tilikete C, Bernard M, Vighetto A (2009) Predicting visual outcome after treatment of pituitary adenomas with optical coherence tomography. Am J Ophthalmol 147:64-70. doi:10.1016/ j.ajo.2008.07.016 